\title{
The Analysis of Electrolyte Chemistry Pictorial Material in Lower Secondary School Chemistry Textbooks in Slovenia Based on Developed Quality Criteria
}

\section{Analýza obrazových materiálů z tématu chemie elektrolytů ve slovinských učebnicích chemie pro základní školy s využitím vytvořených kritérií kvality}

\author{
Nina Zupanc ${ }^{1, *}$, Iztok Devetak ${ }^{1}$ \\ ${ }^{1}$ Faculty of Education, University of Ljubljana, Kardeljeva ploščad 16, 1000 Ljubljana, Slovenia; nina.zupanc@pef.uni-lj.si
}

The textbook as a learning tool and learning resource contributes significantly to the effectiveness of the teaching or learning process itself, while at the same time promotes and facilitates independent learning. The main purpose of this research was to develop quality criteria after which textbooks for Chemistry in lower secondary school were evaluated. This paper presents the analysis of electrolyte chemistry pictorial material presented in chemistry textbooks. When it comes to validating textbooks in Slovenia, there are no unified criteria. The development of the criteria included an overview of the objectives set in the chemistry curriculum. Criteria were made for textbooks used in 8th and 9th grade of lower secondary school (students age 13-15 years). Chemistry textbooks were validated in the school year 2018/2019. When analysing criteria related to textbook representations, the sub-microscopic representations and hybrid representations are the least common features in the textbooks.

Učebnice jako učební nástroj a prostředek významně přispívá $\mathrm{k}$ efektivitě samotného vyučovacího procesu a zároveň podporuje a usnadňuje nezávislé učení. Hlavním účelem tohoto výzkumu bylo vytvořit kritéria kvality, na základě kterých byly hodnoceny učebnice chemie pro základní školy. Tento článek obsahuje analýzu obrazového materiálu použitého $\mathrm{v}$ tématu chemie elektrolytů v učebnicích chemie. Pokud jde o ověřování učebnic ve Slovinsku, neexistují jednotná kritéria. Vypracování kritérií zahrnovalo přehled cílů stanovených $\mathrm{v}$ kurikulu pro obor chemie. Kritéria byla vytvořena pro učebnice používané v 8. a 9. ročníku základní školy (žáci ve věku 13-15 let). Učebnice chemie byly analyzovány ve školním roce 2018/2019. Při ověření kritérií týkajících se učebnicových reprezentací jsou submikroskopické a hybridní reprezentace nejméně běžnými v analyzovaných učebnicích.

\author{
Key words: \\ lower secondary school, \\ chemistry, textbooks \\ quality criteria of \\ textbooks, pictorial \\ material.
}

Received 3/2021

Revised 5/2021

Accepted 5/2021

\section{Introduction}

Learning in the digital age is characterised by a richness of information from different sources, provided to learners by various means, usually supported by Information and Communication Technology (ICT), such as the internet, etc. However, textbooks play a central role in supporting effective teaching and learning of science, as their intention at certain levels of education means that they should be correlated with the national curriculum for a given subject. The textbook is related to the subject or module and to a specific education level. The textbook as a learning tool and learning resource contributes significantly to the effectiveness of the teaching or learning process itself, while at the same time promotes and facilitates independent learning. In the textbook, scientific content is appropriately structured, revised and simplified because the users (students) do not have sufficient prior knowledge of the content to be able to understand it in its unprocessed form (Kovač, 2005). Marentič Požarnik (2016) points out that it is important that learning from the textbook is adapted to the student. She suggests that textbooks authors should consider: (1) taking into account the students' cognitive ability, understanding and experience, (2) using a language appropriate to the student's level of cognitive ability, (3) structure the subject and increase the transparency of the text (titles, subheadings, footnotes), (4) promote reading comprehension and higher cognitive activities in various ways, (5) pay attention to illustrations in the text (diagrams, sketches, pictures). The research TIMSS 2007 showed that $53 \%$ of Slovenian students in the 8 th grade had teachers that use a textbook as a primary source of teaching, which is the same as average international results show (Svetlik et al., 2007). A textbook as an additional source of teaching is used among $47 \%$ of teachers; this is slightly above the world average according to the research. $34 \%$ of teachers in Germany reported that they use the textbook to broaden their own knowledge (Bölsterli et al., 2014). Mohammed and Kumari (2007) analysed teachers experience with the use of science textbooks and found out that teachers had difficulties recognizing mistakes in the textbooks. 


\section{Theoretical background}

One of the most cognitive challenging topics for students in lower secondary school chemistry is electrolyte chemistry. Research show (Devetak et al., 2009a, 2009b; Devetak et al., 2004; Mulford \& Robinson, 2002; Šegedin, 2000) that many misconceptions can be developed if this topic is not presented adequately in the chemistry classroom. Students develop different misconceptions such as not knowing the particles in basic aqueous solutions (Devetak et al 2009a). Devetak et al. (2004) reported that secondary school students do not understand the particulate nature of the solutions and are not able to present graphically the arrangement of particles of the solvent in the solution. They either draw the particles so that they were not randomly arranged or they draw a solution in which the arrangement of the particles represented the solvent as a precipitate, at the bottom of the beaker. The results of the research (Devetak, et al., 2009b) show that the most frequent misconceptions ( $73.7 \%$ of all sub-microrepresentations) regarding solutions of ionic substance was the wrong particle (molecule) drawn in the solution instead of separate ions. The results also indicate that students show many different inconsistencies regarding the explanations of the drawn particles with their names in the legend. Mulford and Robinson (2002) researched students understanding of chemical reactions and they stated that the correct sub-microrepresentation of the reaction mixture after the reaction, based on the given reaction equation and reactant legend, was chosen correctly by only $11 \%$ of the students in the pre-test and $20 \%$ in the end-of-semester test. However, more than $60 \%$ of the test takers in both tests chose answers that gave an incorrect sub-micropresentation of the final state according to the law of conservation of mass. A similar research was conducted by Šegedin (2000) who found that only $9 \%$ of students correctly converted the chemical reaction equation into a sub-microrepresentation of the mixture of product and excess reactant after the reaction between hydrogen and oxygen. However, a sub-microrepresentation with a legend for the reactant mixture before the reaction was given. He also noted that as many as $16 \%$ of the students did not draw oxygen molecule that were not used in the chemical reaction. Even $58 \%$ of the participants did not adhere to the law of conservation of mass in any way.

In the textbooks we find various visual representations, i.e. photos, diagrams, tables, drawings and graphs. According to some authors, representations should not be to complex and should be adapted to student's cognitive level (Cook, 2008). The work of Levias Pozzer and Roth (2003) indicates that textbook authors attend to the appropriate integration of the different representational means so that they assist students' in making sense of the content. Furthermore, the use of single photographs often does not allow a reader to disclose what really matters, a series of contrasting photographs, on the other hand makes salient variation that are more likely to lead students' to identify the crucial and learning aspects. Levias Pozzer and Roth (2003) suggest that every photograph should have an appropriate caption associated with it through an indexical reference in the main text. The caption should add enough information to guide the reader through perceptual analysis and therefore interpretation of the photograph, identifying relevant details and associating the figure with the main text. For the indexical reference, the authors suggest that the illustration (photo and caption) should be explicitly linked to the main text by an indexical reference, preferably immediately after the first mention of the object or phenomenon in the main text. Centering or focusing the relevant object or phenomenon in the photo highlights what is important. In some situations, arrows and other signs placed directly over the photo can help highlight important details in the photos. However, when there is information to be obtained from the dialectically related caption and photo, students miss out on an important resource for understanding the topic they are studying.

The study of Lee (2010) reports that up to $50 \%$ of textbook space is devoted to illustrations in addition to a lack of coherence between the illustration and the associated content. Other studies show a worrying trend towards the increased use of photographs and other "decorative" graphics rather than explanatory illustrations to make texts more familiar and less challenging (Lee, 2010; Slough, 2010).

Mayer (2014) points out that representations draw the student's attention to certain specific elements that enable him/her to make mental connections between the elements and thus promote meaningful learning that forms the basis for problem solving. His theory of multimedia teaching states that a person who accepts information from two sources (e.g. image and word) remembers more than if he/she receives information from a single source, and that is why textbooks should include both. In textbooks we can find different types of representations. Realistic representation represent reality according to the optical perception of people, drawings or photographs can be counted among the realistic images. Conventional representations may include diagrams, sketches, charts, maps, models of molecules. Hybrid representations combine a realistic and conventional way of representation (Devetak et al., 2010).

In chemistry, concepts can be presented on three levels, the macroscopic, the sub-microscopic and the symbolic level, which could be imagined as the corners of a triangle in which no form of presentation is superior to the others, but rather complements one another (Johnstone, 1991). All three levels must 


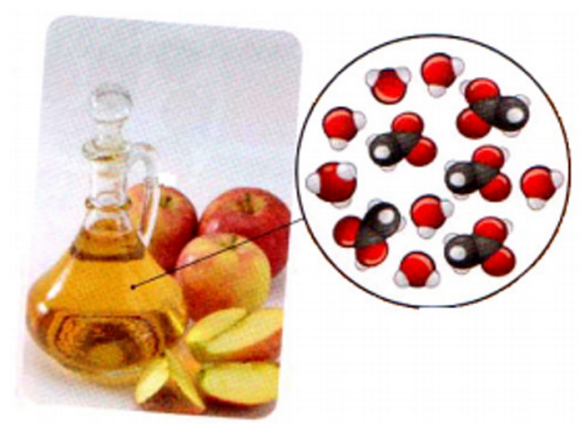

Fig. 1: Example of a hybrid image in a textbook represents acetic acid on a sub-microlevel and vinegar on a macroscopic level (Cvirn Paviln et al., 2016)

overlap meaningfully in the learning process in order to create a suitable mental model of the concept (Devetak \& Glažar, 2007). The effective overlapping of all three levels also allows students not to create misconceptions. Macroscopic imaging is about the actual state of a phenomenon (Johnstone, 1991). This means that the phenomenon is concrete for the student and can be described adequately (Devetak, 2007). Observations that are recognized by students at the macroscopic level are explained by theories based on atomic, molecular or ion level (Johnstone, 1991). Like the macroscopic level, the sub-microscopic level represents the actual state of a particular phenomenon and is the key to understanding chemical concepts before they are symbolically illustrated (Johnsotne, 2000). Sub-micro representations (SMRs) can be used to represent chemical concepts at the particle level, which can be represented as static or dynamic representations (Devetak \& Glažar, 2010). The application of the macro, sub-micro, and symbolic levels of chemical concept representations (chemistry triplet) at all levels of education is an essential part of teaching and learning chemistry, textbooks should include all three levels. Researchers have subjected the ideas of the chemistry triplet (presented by Johnstone) to different adaptations and reinterpretations (Taber, 2013, p. 158).

It is often assumed that students understand the SMRs and learn efficiently with them because textbook authors (usually chemists) can use them simultaneously as part of a triple representation of chemical-chemical concepts. However, the presence of SMRs in a textbook does not guarantee efficient learning. According to Stieff et al. (2016) representational competence encompasses certain set of skills for constructing, selecting, interpreting and using disciplinary representations for communication, learning or problem solving. Research findings (Stull et al., 2012) indicate that the learning success of students with SMRs is significantly influenced by representational competence in chemistry. Kozma and Russell (2005) explained their role in the learning of chemistry, since in order to acquire professional competence in this field, students need to master a certain set of skills, e.g. the ability to analyse characteristics of a representation, to transform one representation into another. In accordance with Davidowitz and Chittleborough (2009) the use of chemical representations at the sub-micro and symbolic levels is as important as those on macroscopic level, the symbolic level helps students to understand the relation between the macro and sub-micro level of different chemistry phenomena.

Gabel (1999) found that while teaches are able to translate between different representational levels, they do not make an effort to integrate these levels in chemistry class.

Gkitzia et al. (2011) developed a rubric form that was applied for analysis of Greek grade 10 textbooks. They found that $23.6 \%$ of the representations are at the macroscopic level, $19.1 \%$ of representation are at the sub-microscopic level and $23.6 \%$ of the representations are at the symbolic level. The most common type of representation is a combination of macroscopic and symbolic representation. With to relatedness to text, more than half of the images were completely related to the corresponding chemical phenomena, but on the other hand, findings on the existence and properties of captions showed that about half of the visual representations were either problematic or had no caption.

Nyachwaya and Wood (2014) used the rubric form developed by Gkitzia et al. (2011) to investigate the nature and types of representations used in physical chemistry textbooks in the US. The results show that $85 \%$ of the representations were symbolic representations.

Kapici and Acikalin-Savasci (2015) analysed visual representations about the particulate nature of matter across grades 6-8 science textbooks used in Turkey. They found that macroscopic representations were the most common, followed by sub-microscopic, then symbolic. The fewest representations used were hybrid. Their results indicate that 4 out of 10 images were completely related and linked. A significant finding was that more than half $(63 \%)$ of the images had no captions. Shehab and BouJaoude (2017) performed an analysis of representations in of Lebanese textbooks grade 10 and grade 11. They found out that in grade 10 textbooks, $53 \%$ of textbook representations were on a macroscopic level, followed 
by the sub-microscopic level (23\%), for grade 11 textbooks the rate was $67 \%$ of representations were on macroscopic level and $18 \%$ of representations were on sub-microscopic level. Only $2 \%$ of representations in both textbook grades were classified as Hybrid. Most of the representations were completely related to the text, but were not accompanied by proper captions (Shehab \& BouJaoude, 2017). Demirdöğen (2017) examined chemical representations presented in four Turkish high school chemistry textbooks. His findings revealed that representation most frequently used were at macroscopic level. The representations were completely related to the text. Marinč (2010) did a similar analysis on Slovenian chemistry school textbooks that were validated in the school year 2009/2010. She analysed the visual material in chemistry textbooks in the 8th and 9th grade of primary school in Slovenia and it she found out that the majority of representations in textbooks are on a symbolic level, followed by the macroscopic level representations. Text also plays a major role in chemistry textbooks, since comprehending new information depends on both student and textual characteristics (Rusek \& Vojír, 2019). Research has shown that inaccurate or incomprehensible texts can cause students' misconceptions (Bergqvist \& Chang Rundgren, 2017); Pedrosa \& Dias, 2000; Sanger \& Greenbowe, 1993). Rusek and Vojír., (2019) conducted an analysis of text difficulty in lower secondary Czech chemistry textbooks. Their research is focused on semantic difficulty by comparing particular textbooks in one textbook series and the difficulty of selected topics within the textbooks. The method used in their research is called Nestler-Průcha-Pluskal and it is based on variety of term categories (Rusek \& Vojír, 2019). They found that in the analysed Czech chemistry textbooks (for grade 8 and 9) no systematic approach towards scientific literacy and reading literacy was found, the text difficulty was not constant. Rusek and Vojír (2019) also discovered that there were textbook series where the 8th grade textbook was more difficult, semantically and syntactically, than the 9th grade textbooks (Rusek \& Vojír, 2019, p. 7). The discovered inequality suggests that that text difficulty should also be considered as a criterion in textbook analysis.

\section{Aim of the research}

The main purpose of the research was to develop quality criteria after which we evaluated textbooks for Chemistry in primary school. This paper focus on the criteria developed for analysing pictorial elements in chemistry textbooks. When it comes to validating textbooks in Slovenia, there are no unified criteria; therefore, we can spot inconsistencies in validated textbooks, not to mention that validation might be under pressure from the publisher. The development of the criteria included an overview of the objectives set in the chemistry curriculum. The criteria for evaluating textbooks are useful in chemistry education because they determine: whether the textbook is appropriate for the students at the specific cognitive level, whether it motivates students to learn chemistry, whether the textbook contains contemporary findings in the field of chemistry and the natural sciences, and whether it follows research driven modern trends in chemistry education (Stern \& Roseman, 2003). Due to the developed criteria, the electrolyte chemistry pictorial material in selected textbooks was analysed and some suggestions which textbooks fits best to the specific level of chemistry education were made.

Research Questions:

1. What general characteristic of pictorial representations are included in the analysed textbooks?

2. What type specific pictorial representations are included and how frequently the triple nature of chemical concepts is included in analysed textbooks.

\section{Methodology}

The research is based on a quantitative research approach. A descriptive, non-experimental method of educational research was used (Sagadin, 1993). The criteria were developed based on literature studies of comparable criteria for the validation of textbooks used in other countries and adapted for Slovenian chemistry textbooks. The criteria were used for the analysis and comparation of chemistry textbooks in the 8th and 9th grade in Slovenian primary schools, which were valid in the school year 2018/2019 and are still available in the current school year to the students. This paper focus on the criteria developed for analysing pictorial material in chemistry textbooks. Based on theoretical starting points and a review of literature, a matrix was created for the analysis of textbooks. The data collected were processed using quantitative methods according to the type of criterion. 


\subsection{Sample}

The Sample represents textbooks for chemistry in the 8th and 9th grades of lower secondary school, which were validated in the school year 2018/2019. Textbooks with the same title and authors, a more recent edition of the textbook was analysed. In textbooks where the electronic and the physical version are identical, the physical version was analysed.

Tab. 1: List of analysed textbooks

\begin{tabular}{|c|c|c|c|c|c|}
\hline $\begin{array}{l}\text { Original textbook title } \\
\text { (translated textbook title) }\end{array}$ & Author(s) & Publisher & $\begin{array}{c}\text { Year of } \\
\text { publication }\end{array}$ & $\begin{array}{l}\text { Number } \\
\text { of pages }\end{array}$ & Grade \\
\hline $\begin{array}{l}\text { Kemija 8, i-učbenik } \\
\text { (Chemistry } 8, \text { i-textbook) }\end{array}$ & $\begin{array}{l}\text { Sajovic, I., Wissiak Grm, K., } \\
\text { Godec, A.,Kralj, B., Smrdu, A., } \\
\text { Vrtačnik, M., Glažar, S. }\end{array}$ & $\begin{array}{l}\text { Zavod RS } \\
\text { za šolstvo }\end{array}$ & 2014 & 264 & 8 \\
\hline $\begin{array}{l}\text { Moja prva kemija } \\
\text { (My first chemistry) }\end{array}$ & $\begin{array}{l}\text { Vrtačnik, M., Wissiak Grm, K.S., } \\
\text { Glažar, S. A., Godec, A. }\end{array}$ & Modrijan & 2015 & 240 & 8,9 \\
\hline $\begin{array}{l}\text { Od atoma do molekule } 8 \\
\text { (From atom to molecule } 8 \text { ) }\end{array}$ & Smrdu, A. & Jutro & 2012 & 128 & 8 \\
\hline $\begin{array}{l}\text { Kemija danes } 2 \\
\text { (Chemistry today } 2 \text { ) }\end{array}$ & $\begin{array}{l}\text { Graunar, M., Podlipnik, M., } \\
\text { Mirnik, J. }\end{array}$ & $\overline{\text { Dzs }}$ & 2016 & 152 & 9 \\
\hline $\begin{array}{l}\text { Peti element } 9 \\
\text { (Fifth element) }\end{array}$ & $\begin{array}{l}\text { Devetak, I., Cvirn Pavlin, T., } \\
\text { Jamšek, S. }\end{array}$ & Rokus Klett & 2011 & 77 & 9 \\
\hline $\begin{array}{l}\text { Pogled v kemijo } 9 \\
\text { (Look into chemisty 9) }\end{array}$ & Kornhauser, A., Frazer, M. & $\begin{array}{l}\text { Mladinska } \\
\text { knjiga }\end{array}$ & 2005 & 140 & 9 \\
\hline
\end{tabular}

All the analysed textbooks contain topics with concepts that are defined by national chemistry curriculum.

\subsection{Research Instrument}

A matrix for analysing textbooks in Excel was created. The criteria have been divided into two main strands: a) the content-didactic criteria and b) the organisational-technical criteria. Strand a) was further divided into: (1) thinking, (2) tasks, (3) vocabulary and language, (4) content. Strand b) was further divided into: (5) text and representations, (6) internal structure, (7) external appearance. For the purpose of this paper, only the results of the analysis of the category (5) test and representations are presented. The results were processed using Microsoft Office Excel. No textbook was considered preferential.

Table 2 presents the analysis criteria for organisational and technical criteria covering the text and representations and a description of the subject of the analysis for each criterion.

Tab. 2: Criteria related to text and image, and subject of the analysis of the criterion

\begin{tabular}{ll}
\hline Criteria related to text and representations & Subject of analysis \\
$\begin{array}{l}\text { The representation is on the same page as the text } \\
\text { (Piht et al., 2013). }\end{array}$ & $\begin{array}{l}\text { In this context, it was analysed whether the } \\
\text { representation was on the same page as the text (i.e. } \\
\text { whether the Mayer principles were respected). }\end{array}$ \\
$\begin{array}{l}\text { Formulas and schemes are understandable and } \\
\text { logical (Piht et al., 2013). }\end{array}$ & $\begin{array}{l}\text { It was analysed whether the schemes, formulas and the } \\
\text { graphs were understandable and in correlation with text. }\end{array}$ \\
\hline $\begin{array}{l}\text { Characters/Illustration/diagram does not contain } \\
\text { more than } 7 \text { elements or objects (Piht et al., 2013). }\end{array}$ & $\begin{array}{l}\text { How many items are displayed in } \\
\text { images/illustrations/schemes has been analysed. }\end{array}$ \\
$\begin{array}{l}\text { Figure/Illustration/scheme is in correlation with } \\
\text { text (Piht, et al., 2013). }\end{array}$ & $\begin{array}{l}\text { It was analysed whether the images/illustrations/ in } \\
\text { chemistry textbooks are related to text. }\end{array}$ \\
$\begin{array}{l}\text { In the textbook we find presentations at macroscopic } \\
\text { level (e.g pictures, sketches, photographs, film } \\
\text { cuttings, .. ) (Bölsterli et al., 2017). }\end{array}$ & $\begin{array}{l}\text { It was analysed how many presentations in the } \\
\text { chemistry textbooks are at macroscopic level. }\end{array}$ \\
$\begin{array}{l}\text { In the textbook we find presentations of particles at } \\
\text { sub-microscopic level (2-D or 3-D } \\
\text { sub-microprezentation) (Bölsterli et al., 2017). }\end{array}$ & $\begin{array}{l}\text { It was analysed how many sub-micro representations are } \\
\text { in the chemistry textbooks. }\end{array}$ \\
$\begin{array}{l}\text { In the textbook we find presentations at the } \\
\text { symbolic level (mathematical formulas, symbolic } \\
\text { chemical language) (Devetak et al., 2007) }\end{array}$ & $\begin{array}{l}\text { It was analysed how many of the presentations are in } \\
\text { the chemistry textbooks at the symbolic level. }\end{array}$ \\
$\begin{array}{l}\text { The textbook contains conventional images (graphs, } \\
\text { sketches, schemes, maps, molecular models) } \\
\text { (Devetak et al., 2010) }\end{array}$ & $\begin{array}{l}\text { It was analysed how many conventional images are in } \\
\text { chemistry textbooks. }\end{array}$ \\
$\begin{array}{l}\text { The textbook contains hybrid images (Devetak et } \\
\text { al., 2010). }\end{array}$ & $\begin{array}{l}\text { It was analysed how many hybrid images are in } \\
\text { chemistry textbooks. }\end{array}$ \\
\hline
\end{tabular}




\subsection{Results}

The results are presented only for the organisational and technical criteria covering the textual and pictorial elements in textbooks. The results are presented for the topic: electrolyte chemistry. The topic occurs in textbooks for 8th grade and three textbooks for 9th grade, because textbook authors are not obligated to write textbook topic in the same order as the topic (objectives) that are written in the chemistry curriculum for primary school.

Tab. 3: Textbook representations on the electrolyte chemistry in Slovenia lower secondary chemistry textbooksgeneral characteristics

\begin{tabular}{lcccccc}
\hline Criteria (YES/NO) & $\begin{array}{c}\text { Kemija } \\
\text { danes 2 }\end{array}$ & $\begin{array}{c}\text { Peti } \\
\text { element 9 }\end{array}$ & $\begin{array}{c}\text { Pogled } \\
\text { v kemijo 9 }\end{array}$ & $\begin{array}{c}\text { Od atoma } \\
\text { do molekule 8 }\end{array}$ & $\begin{array}{c}\text { Moja prva } \\
\text { kemija }\end{array}$ & $\begin{array}{c}\text { i-učbenik } \\
\text { kemija 8 }\end{array}$ \\
$\begin{array}{l}\text { The representation is on the } \\
\text { same page as the text. }\end{array}$ & YES & YES & YES & YES & YES & YES \\
\hline $\begin{array}{l}\text { Formulas and schemes are } \\
\text { understandable and logical. }\end{array}$ & YES & YES & YES & NO & NO & YES \\
$\begin{array}{l}\text { Characters/Illustration/diagram } \\
\begin{array}{l}\text { does not contain more than } \\
\text { elements or objects. }\end{array}\end{array}$ & YES & YES & YES & YES & YES & YES \\
$\begin{array}{l}\text { Figure/Illustration/scheme is in } \\
\text { correlation with text. }\end{array}$ & YES & YES & YES & YES & YES & YES \\
\hline
\end{tabular}

For the analysed topic, the authors of the textbooks took into account that the pictures are on the same page as the text and that they have a reference to the text. All the formulas and schemes analysed were understandable and appropriate, except for the presentation of the aqueous solutions in the textbook From atom to molecule 8, in which the water molecules are drawn and the background is coloured blue, this representation can cause misunderstanding and representation in textbook My first chemistry where you can not read why the chlorine ione is highlighted in purple.

Tab. 4: Textbook representations on the topic electrolyte chemistry in Slovenia lower secondary chemistry textbooks at thetriple nature of chemical concepts

\begin{tabular}{|c|c|c|c|c|c|c|}
\hline$\overline{\text { Criteria }(f)}$ & $\begin{array}{c}\text { Kemija } \\
\text { danes } 2 \\
(f)\end{array}$ & $\begin{array}{c}\text { Peti } \\
\text { element } 9 \\
(f) \\
\end{array}$ & $\begin{array}{c}\text { Pogled } \\
\text { v kemijo } 9 \\
(f) \\
\end{array}$ & $\begin{array}{c}\text { Od atoma } \\
\text { do molekule } 8 \\
(f)\end{array}$ & $\begin{array}{l}\text { Moja prva } \\
\text { kemija } \\
(f)\end{array}$ & $\begin{array}{c}\text { i-učbenik } \\
\text { kemija } 8 \\
(f) \\
\end{array}$ \\
\hline $\begin{array}{l}\text { In the textbook we find representations } \\
\text { at macroscopic level (e.g pictures, } \\
\text { sketches, photographs, film } \\
\text { cuttings, ... }\end{array}$ & 45 & 18 & 20 & 32 & 24 & 30 \\
\hline $\begin{array}{l}\text { In the textbook we find representations } \\
\text { of particles at sub-microscopic level } \\
\text { (2-D or } 3 \text {-D sub-micropresentation) }\end{array}$ & 10 & 7 & 0 & 3 & 12 & 11 \\
\hline $\begin{array}{l}\text { In the textbook we find representations } \\
\text { at the symbolic level (mathematical } \\
\text { formulas, symbolic chemical language) }\end{array}$ & 50 & 20 & 2 & 46 & 13 & 20 \\
\hline $\begin{array}{l}\text { The textbook contains conventional } \\
\text { images (graphs, sketches, schemes, } \\
\text { maps, molecular models) }\end{array}$ & 23 & 9 & 4 & 11 & 10 & 3 \\
\hline The textbook contains hybrid images & 8 & 6 & 0 & 2 & 9 & 6 \\
\hline
\end{tabular}

In the analysed textbooks we find most representations on the symbolic level, most of them in the textbook Chemistry today $2(f=20)$, and none in the textbook Look into chemistry $9(f=0)$. The macroscopic level is most represented in the textbook Chemistry today $2(f=45)$ and in the textbook From atom to molecule $8(f=32)$. In the analysed chapter, all textbooks contained very few submicrorepresentations. Textbook Look into 9 had only 2 sub-microrepresentations $(f=2)$.

Most of the conventional representations are found in textbook Chemistry today $2(f=23)$ and in Textbook From atom to molecule $8(f=11)$, at least in the I-textbook chemistry $8(f=3)$ and in Textbook Look into chemistry $9(f=4)$. Most of the hybrid representations can be found in the textbook My first chemistry $(f=9)$ and in the textbook Chemistry today $2(f=7)$ and Fifth element 9 $(f=7)$, From atom to molecule 8 had only two hybrid representations $(f=2)$. The textbooks Look into Chemistry 9, did not have any hybrid representations. 
Tab. 5: Examples of sub-microrepresentation form analysed textbooks

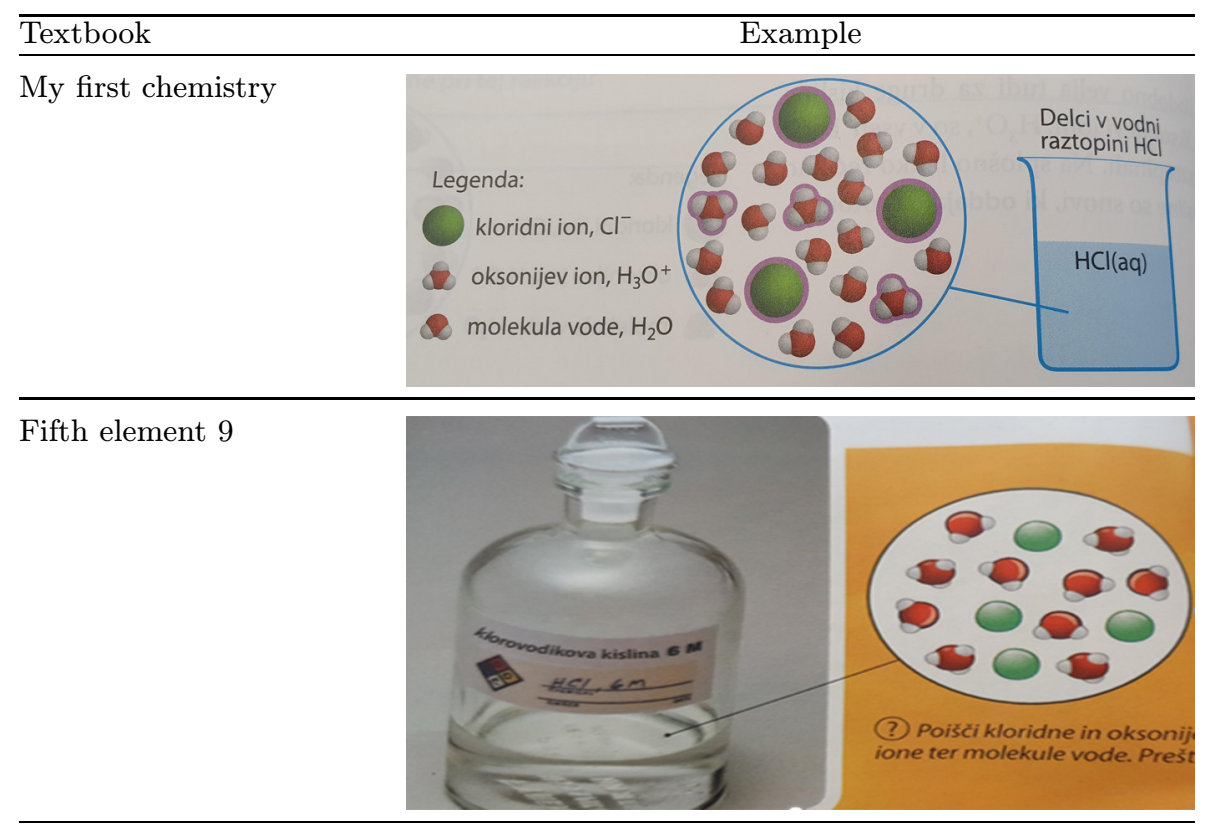
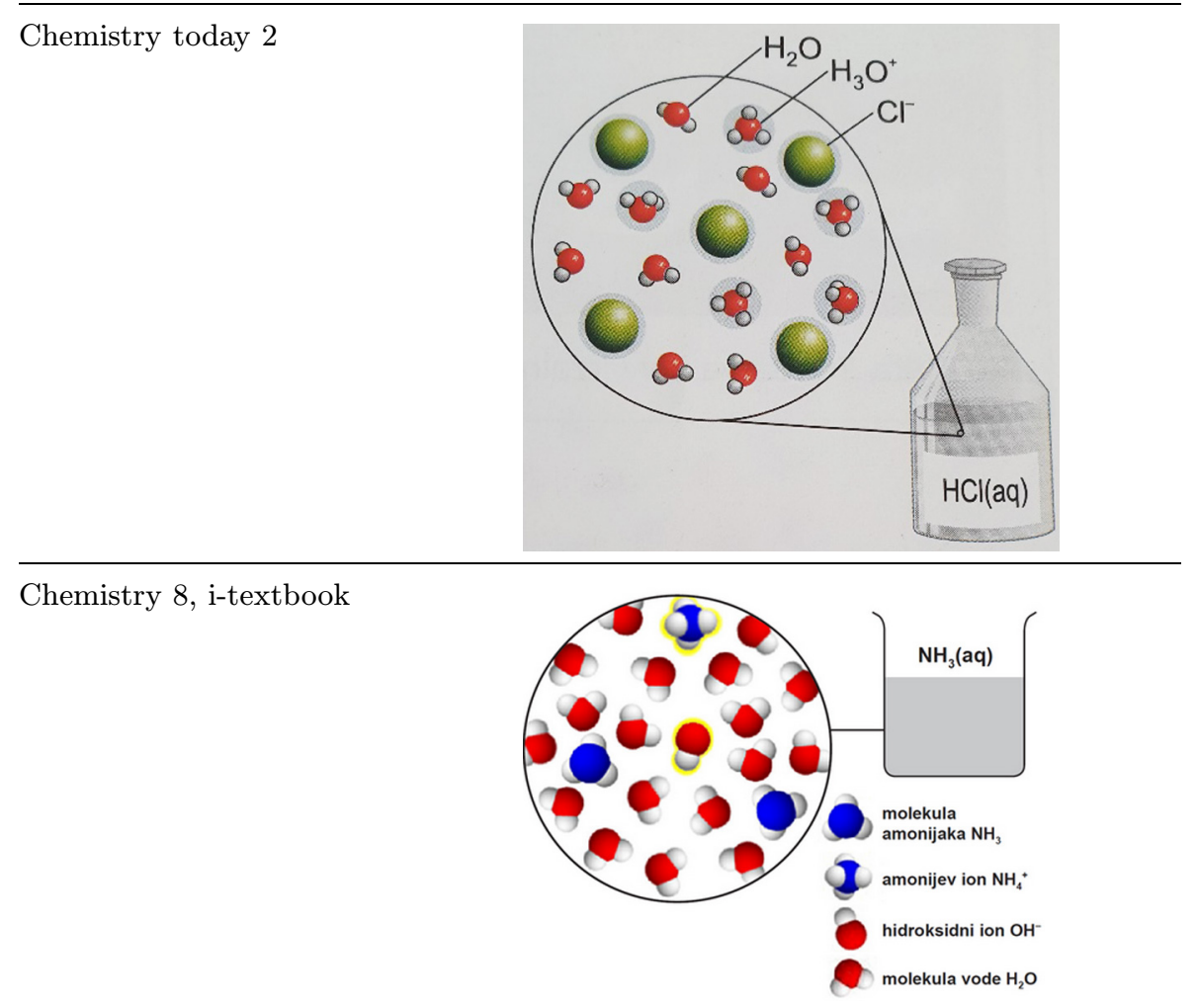

From atom to molecule 8

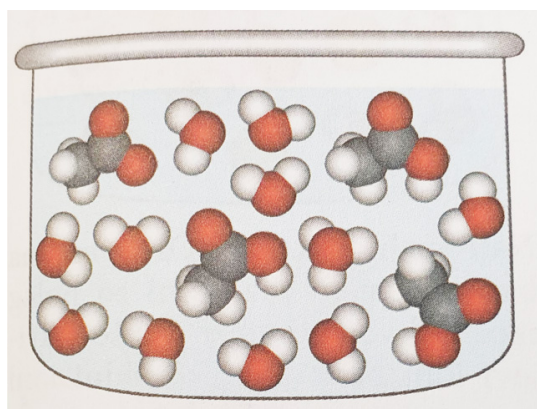


The textbooks Chemistry 8, i-textbook, Chemistry today 2 and My first chemistry did have a legend for particles that are presented in the sub-microrepresentation. In all of these textbooks the text was related to the sub-microrepresentation, containing an explanation of the image, followed by questions such as: which particle indicate that the solution is acid or base, and which particles indicate the solution is an electrolyte. In the textbook Chemistry 8, i-textbook, the text did not state why some particles are yellow coloured. The textbook Fifth element 9 did not have a legend for particles presented on the image, but the text under the image did ask students to pick which particles are water molecules and which are hydronium ions. The sub-microrepresentation in textbook From atom to molecule 8 can cause some misunderstanding, because in the solution we see water molecules but the background is also coloured blue (which represents water). The textbook Look into chemistry 9 did not have any sub-microrepresentations present.

\section{Discussion}

The purpose of this paper is to present the characteristics of the pictorial material in Slovenian chemistry textbook for students in lower secondary school. The first research question deals with general characteristics of pictorial representations in analysed textbooks. All the authors of analysed textbooks acknowledged Mayer's (2014) principles, so all the pictorial material is on the same page as the text it refers to. All analysed textbooks, except the textbook My first Chemistry (Moja prva kemija) meet the criteria for general characteristics. The second research question deals with type specific pictorial representations and how frequently the triple nature of chemical concepts are included in analysed textbooks. Our results for the second research question are consistent with the findings of (Nyachwaya \& Wood, 2014; Shehab \& BouJaoude, 2017 and Gkitzia et al., 2011) who reported "a bias towards a macro-symbolic orientation in the textbook". In the introductory chapters of textbooks, it is expected that textbooks macroscopically present chemical phenomena, as this (macroscopic) level a representation has potential to attract and stimulate students' interest in chemistry (Upahi \& Ramnarain, 2019). In a longitudinal study by Lee (2010), the author examined the extent to which representations in textbooks published in the United States have changed over the past six decades. It was found that high-fidelity images, such as photographs, were more likely to be used than the schematic and explanatory images to promote student familiarization. In explaining the criteria for evaluating the quality of science textbooks, Devetak and Vogrinc (2013) noted that visual materials are sometimes used to stimulate recall of prior information. Although many variables related to graphic features were considered, the researchers failed to extract the overall graphic/representative quality of elementary science textbooks.

The results of our study indicated a very small proportion of sub-microscopic representations in the textbooks and this fails to address the important point that many chemical phenomena are understood at the particulate level (Davidowitz \& Chittleborough, 2009). It is equally important that textbook authors give attention to this form of representation. In a study of Kapici and Acikalin-Savasci (2015) on how visuals that focus on the particulate nature of matter are used in middle school science textbooks, it is also reported a less frequent use of the sub-microscopic levels in chemical explanations. Analysed textbooks contained very few hybrid images. Researchers (Carney \& Levine, 2002) recommend that illustrations/schematics/graphics in textbooks are simple and contain fewer elements, as unnecessary additions only confuse the students. Hinze et al., (2013) suggests that understanding the kinds of information and inferences that the visualisations in various learning materials provide requires explicit instruction and practice. In all analysed textbooks, representations were on the same page as the text. The importance of relatedness of text to representations in terms of completeness and linkage is that students do not have to try to establish a link and interpret the image in relation to the text by themselves (Levias Pozzer \& Roth, 2003). Irez (2010) examined five secondary biology textbooks and investigated the treatment of the nature of science. Lee (2010) examined the design and use of representations that have changed over six decades in the United States and argued that the diagrams used in textbooks are becoming increasingly iconic. Science was found to be represented as a collection of facts rather than a dynamic process of generating and testing alternative explanations about the nature of science. The study identified a problem in the textbooks that may be generating alternative ideas about science as the scientific domains were presented as collections of facts rather than dynamic processes. Hegarty and Just (1991) who classified diagrams used in science teaching context into three types which include: Iconic diagrams, schematic diagrams, and charts and graphs. Iconic diagrams are realistic pictures or drawings of concrete objects. They are effective in helping students identify appearance and structure that are amenable to visual inspection. Schematic diagrams are highly abstracted from real-world entities and preserve only the physical relationships of the target information. Consequently,interpreting a schematic diagram requires learners todecode the abstract content of the diagram and make a connection to the 
target concept. The third category, diagrams and graphs,represents the relationships of quantitative data. It is often necessary for the reader to identify all independent variables before making an interpretation because abstract meanings and numerical data are embedded in charts and graphs

\section{Conclusion}

Chemistry requires the integration of chemical representations to understand phenomena in textbooks and during classroom instructions, for effective teaching and learning of chemical concepts to take place. When the teacher may be limited in portraying these phenomena during class, textbook becomes a vital and indispensable tool for conveying an adequate understanding of the underlying concepts and principles of a chemical phenomenon.

The goal of this study was to develop criteria for textbook analysis that can help the commission in the process of textbook validation, as well as the teacher in the selection of a textbook. In addition, the criteria can be a good tool for authors in designing new textbooks. The criteria were developed for 8th and 9th grade elementary chemistry textbooks. In the 2018/2019 school year, the validated textbooks for chemistry in primary school were analysed. The results in this paper are presented only for the organisational and technical criteria covering the pictorial elements. Textbook authors need to acknowledge that if different levels of chemistry representations are well-integrated in textbooks, they have the potential to reduce students' difficulties in understanding chemical concepts and promote their learning. However, teachers who understand the role of pictorial material in chemistry and its connection to textual part of the textbooks they use in classroom may also be able to use these textbooks more efficient to promote meaningful learning at each level of education.

\section{Acknowledgment}

We would like to thank the project Za kakovost slovenskih učbenikov [For the Quality of Slovene School Textbooks] for received financial support. The investment is co-financed by the Republic of Slovenia and the European Union from the European Social Fund.

\section{References}

Bergqvist, A., \& Chang Rundgren, S. N. (2017). The influence of textbooks on teachers' knowledge of chemical bonding representations relative to students' difficulties understanding. Research in Science ES Technological Education, 35(2), 215-237. https://doi.org/10.1080/02635143.2017.1295934

Bölsterli, K., Wilhelm, M., \& Rehm, M. (2014). Empirisch gewichtetes Schulbuchraster für den naturwissenschaftlichen kompetenzorientierten Unterricht. Perspectives in Science - Special Issues Progress in Science Education, 5(1), 3-13. https://doi.org/10.1016/j.pisc.2014.12.011

Carney, R. N., \& Levine, R. J. (2002). Pictorial Illustrations Still Improve Students' Learning from Text. Educational Psychology Review, 14(1), 5-26. https://doi.org/10.1023/A:1013176309260

Cook, M. (2008). Students Comprehension of Science Concepts Depicted in Textbook Ilustrations. Electronic Journal of Science Education, 12(1), 39-54. https://ejrsme.icrsme.com/article/view/7765

Cvirn Pavlin, T., Devetak, I., \& Jamšek, S. (2016). Peti element 9, učbenik za kemijo v 9. razredu osnovne šole [Fifth element, chemistry textbook for 9th grade] Rokus Klett.

Davidowitz, B., \& Chittleborough, G. (2009). Linking the macroscopic and sub-microscopic levels: diagrams. In J. K. Gilbert \& D. Treagust (Eds.), Multiple representations in chemical education (pp. 169-191). Springer https://doi.org/10.1007/978-1-4020-8872-8_9

Demirdöğen, B. (2017). Examination of chemical representations in Turkish high school chemistry textbooks. Journal of Baltic Science Education, 16(4), 472-499.

http://www.scientiasocialis.It/jbse/files/pdf/vol16/472-499.Demirdogen_JBSE_Vol.16_No.4.pdf

Devetak, I., Urbančič, M., Grm, K.S. W., Krnel, D., \& Glažar, S. A. (2004). Submicroscopic representations as a tool for evaluating students' chemical conceptions. Acta Chimica Slovenica, 51(4), 799-814.

http://acta-arhiv.chem-soc.si/51/graph/acta-51(4)-GA.htm

Devetak, I., \& Glažar, S. A. (2007). Chemistry teachers' mentoring in Slovenian primary and secondary school. In M. Zuljan \& J. Vogrinc (Eds.), Professional inductions of teachers in Europe and elsewhere (pp. 102-115). University of Ljubljana, Faculty of Education https://doi.org/10.13140/2.1.3087.5527

Devetak, I., Vogrinc, J. \& Glažar, S. A. (2009a). Assessing 16-year-old students' understanding of aqueous solution at submicroscopic level. Research Science Education, 39(1), 157-179.

https://doi.org/10.1007/s11165-007-9077-2 
Devetak, I., Lorber, E. D., Juriševič, M., \& Glažar, S. A. (2009b). Comparing Slovenian year 8 and year 9 elementary school pupils' knowledge of electrolyte chemistry and their intrinsic motivation. Chemistry Education Research and Practice, 10(4), 281-290. https://doi.org/10.1039/B920833J

Devetak, I., Vogrinc, J., \& Glažar, S. (2010). States of Matter Explanations in Slovenian Textbooks for Students Aged 6 to 14. International Journal of Environmental and Science Education, 5(2), 217-235. https://files.eric.ed.gov/fulltext/EJ884420.pdf

Devetak, I., \& Vogrinc, J. (2013). The criteria for evaluating the quality of the science textbooks. In M. Kihne (Ed), Critical analysis of science textbooks (pp. 3-15). Springer, Dordrecht. https://doi.org/10.1007/978-94-007-4168-3_1

Gabel, D. (1999). Improving teaching and learning through chemistry education research: a look to the future. Journal of Chemical Education, 76(4), 548-554 https://doi.org/10.1021/ed076p548

Gkitzia, V., Salta, K., \& Tzougraki, C. (2011). Development and application of suitable criteria for the evaluation of chemical representations in school textbooks. Chemistry Education Research and Practice, 12(1), 5-14. https://doi.org/10.1039/C1RP90003J

Hegarty, M., Carpenter, P. A., \& Just, M. A. (1991). Diagrams in the comprehension of scientific texts. In R. Barr, M. L. Kamil, P. B. Mosenthal, \& P. D. Pearson (Eds.), Handbook of reading research $\left(2^{\text {nd }}\right.$ ed., pp. 641-668). Lawrence Erlbaum Associates, Inc.

Hinze, S. R., Rapp, D. N., Williamson, V.M., Shultz, M. J., Deslongchamps, G., \& Williamson, K. C. (2013). Beyond ball-and-stick: Students' processing of novel STEM visualizations. Learning and Instruction, 26(1), 12-21. https://doi.org/10.1016/j.learninstruc.2012.12.002

Irez, S. (2010). Nature of science as depicted in Turkish biology textbooks. Science Education, 93(3), 422-447. https://doi.org/10.1002/sce.20305

Johnstone, A.H. (1991). Why is science difficult to learn? Things are seldom what they seem, Journal of Computer Assisted Learning, 7(2), 75-83. https://doi.org/10.1111/j.1365-2729.1991.tb00230.x

Johnstone, A. H. (2000). Teaching of chemistry-logical or psychological? Chemistry education Research and Practice, 1(1), 9-15. https://doi.org/10.1039/A9RP90001B

Kapici, H., \& Acikalin-Savasci, F. (2015). Examination of visuals about the particulate nature of matter in Turkish middle school science textbooks. Chemistry education Research and Practice, 16(3), 518-536. https://doi.org/10.1039/C5RP00032G

Kovač, M., Kovač Šebart, M., Krek, J., Štefanc, J., \& Vidmar, T. (2005). Učbeniki in družba znanja [Textbooks and society of knowledge]. Znanstveni inštitut Filozofske fakultete.

Kozma, R., \& Russell, J. (2005). Students becoming chemists: Developing representational competence. In J. Gilbert (Eds.), Visualization in science education (pp. 121-146). Kluwer. https://doi.org/10.1007/1-4020-3613-2_8

Lee, V. (2010). Adaptations and Continuities in the use and design of visual representations in US Middle School Science textbooks. International Journal of Science, 32(8), 1099-1126.

https://doi.org/10.1080/09500690903253916

Leivas Pozzer, L., \& Roth, W. (2003). Prevalence, function and structure of photographs in high school biology textbooks. Journal of Research in Science Teaching, 40(10), 1089-1114. https://doi.org/10.1002/tea.10122

Marentič Požarnik, B. (2016). Psihologija učenja in pouka: temeljna spoznanja in primeri prakse [School psychology, research and practice], DZS.

Marinč, M. (2010). Analiza trenutno veljavnih slovenskih učbenikov za kemijo $v$ osnovni in srednji šoli (diplomsko delo) [Analysis of current high school chemistry textbooks] [Diploma thesis]. University of Ljubljana, Faculty of Education.

Mayer, R. (2014). Introduction to Multimedia Learning. In R. Mayer (Eds.), The Cambridge Handbook of Multimedia Learning (pp. 1-24). Cambridge University Press. https://doi.org/10.1017/CBO9781139547369.002

Mohammed, F. R., \& Kumari, R. (2007). Effective use of textbooks: a neglected aspect of Education in Pakistan. Journal of Education for International Development, 3(1), 1-11.

Mulford, D. R., \& Robinson, W. R. (2002). An inventory for alternate conceptions among first-semester general chemistry students. Journal of chemical education, 79(6), 739-744. https://doi.org/10.1021/ed079p739

Nyachwaya, J. M., \& Wood, N. B. (2014). Evaluation of chemical representations in physical chemistry textbooks. Chemistry Education Research and Practice, 15(4), 720-728. https://doi.org/10.1039/C4RP00113C

Pedrosa, M. A., \& Dias, M. H. (2000). Chemistry textbook approaches to chemical equilibrium and student alternative conceptions. Chemistry Education Research and Practice, 1(2), 227-236.

https://doi.org/10.1039/A9RP90024A 
Piht, S., Raus, R., Kukk, A., Kerli, M., \& Riidak, K. (2013). Students interpretations of the $6^{\text {th }}$ grade science textbook design. Procedia-Social and Behavioural Sciences, 112(1), 861-872.

https://doi.org/10.1016/j.sbspro.2014.01.1243

Rusek, M., \& Vojiřr, K. (2019). Analysis of text difficulty in lower-secondary chemistry textbooks. Chemistry Education Research and Practice, 20(1), 85-94. https://doi.org/10.1039/C8RP00141C

Sagadin, J. (1993). Poglavja iz metodologije pedagoškega raziskovanja [Chapters' from pedagogical methodology] Zavod Republike Slovenije za šolstvo in šport.

Sanger, M. J., \& Greenbowe, T. J. (1999). An analysis of college chemistry textbooks as sources of misconceptions and errors in electrochemistry. Journal of chemical Education, 76(6), 853-859. https://doi.org/10.1021/ed076p853

Shehab, S. S., \& BouJaoude, S. (2017). Analysis of the chemical representations in secondary Lebanese chemistry textbooks. International Journal of Science Mathematics Education, 15(5), 797-816. https://doi.org/10.1007/s10763-016-9720-3

Slough, S. W., McTigue, E. M., Kim, S., \& Jennings, S. K. (2010). Science textbooks' use of graphical representation: A descriptive analysis of four sixth grade science texts. Reading Psychology, 31(3), 301-325. https://doi.org/10.1080/02702710903256502

Stern, L., \& Roseman, J. (2003). Can Middle-School Science Textbooks help students learn important ideas? Findings from Project 2061's curriculum evaluation study. Journal of research in science teaching, 41(6), 538-568. https://doi.org/10.1002/tea.20019

Stieff, M., Scopelitis, S., Lira, M. E., \& Desutter, D. (2016). Improving representational competence with concrete models. Science Education, 100(2), 344-363. https://doi.org/10.1002/sce.21203

Stull, A. T., Hegarty, M., Dixon, B. L., \& Stieff, M. (2012). Representational translation with concrete models in Organic Chemistry. Cognition \& Instruction, 30(4), 404-434. https://doi.org/10.1080/07370008.2012.719956

Svetlik, K., Japelj Pavešič, B., Kozina, A., Rožman, M., \& Steblaj, M. (2007). $N$ aravoslovni dosežki Slovenije v raziskavi TIMSS 200\%, mednarodna raziskava trendov znanja matematike in naravoslovja [Timss 200\%, natural science education results in Slovenia], Pedagoški inštitut.

Šegedin, P. (2000). Understanding of chemical and physical change. In A. Glavič \& D. Brodnjak-Vončina (Eds.), Abstracts of the Slovenian chemical days (pp. 451-456). Slovenian Chemical Society.

Taber, K. S. (2013). Revisiting the chemistry triplet: drawing upon the nature of chemical knowledge and the psychology of learning to inform chemistry education. Chemistry Education Research and Practice, 14(2), 156-168. https://doi.org/10.1039/C3RP00012E

Upahi, J. E., \& Ramnarain, U. (2019). Representations of chemical phenomena in secondary school chemistry textbooks. Chemistry Education Research and Practice, 20(1), 146-159. https://doi.org/10.1039/C8RP00191J 